\title{
KaJian Proses Destilasi Fraksinasi Biodiesel Kemiri Sunan (ReUtealis TRISPERMA)
}

\author{
Study on Fractional Distillation Process of Biodiesel from Philippine Tung (Reutealis trisperma)
}

\author{
Fathia Salsabila Emmaputri ${ }^{1}$, Sarifah Nurjanah ${ }^{2}$, Efri Mardawati ${ }^{2}$, M. Ade Moetangad Kramadibrata ${ }^{2}$, \\ Mimin Muhaemin ${ }^{2}$, Wahyu Daradjat ${ }^{3}$, Handarto ${ }^{2}$, Totok Herwanto ${ }^{2}$, S. Rosalinda ${ }^{2}$ \\ ${ }^{1}$ Mahasiswa Departemen Teknik Pertanian dan Biosistem, Fakultas Teknologi Industri Pertanian, \\ Universitas Padjadjaran \\ ${ }^{2}$ Staf Pengajar Fakultas Teknologi Industri Pertanian, Universitas Padjadjaran \\ ${ }^{3}$ Staf Pengajar Fakultas Pertanian, Universitas Padjadjaran \\ Jalan Raya Bandung-Sumedang Km 21, Jatinangor 40600 \\ E-mail: fathiasemma@gmail.com
}

\begin{abstract}
ABSTRAK
Biodiesel merupakan bahan bakar alternatif yang berasal dari minyak nabati. Kemiri sunan (Reutealis trisperma) merupakan salah satu tanaman yang memiliki potensi sebagai bahan baku biodiesel. Untuk mendapatkan mutu biodiesel yang optimal, perlu dilakukan peningkatan asam lemak ester yang relevan melalui proses destilasi fraksinasi. Penelitian ini bertujuan untuk mengetahui pengaruh temperatur destilasi fraksinasi terhadap mutu biodiesel, mengetahui fraksi biodiesel dengan rendemen dan mutu terbaik, serta mengetahui mutu biodiesel kemiri sunan. Metode yang digunakan adalah metode eksperimental dengan analisis deskriptif. Destilasi fraksinasi dilakukan dengan tiga perlakuan suhu yaitu $\mathrm{A}$ $=260-330^{\circ} \mathrm{C} ; \mathrm{B}=330-348^{\circ} \mathrm{C} ;$ dan $\mathrm{C}=348-360^{\circ} \mathrm{C}$. Percobaan dilakukan sebanyak tiga kali ulangan. Hasil penelitian menunjukkan bahwa biodiesel terdestilasi pada perlakuan A dan B. Fraksi biodiesel terbaik apabila ditinjau dari kebutuhan mesin dan kebutuhan proses merupakan fraksi biodiesel hasil perlakuan $A$ dengan perolehan nilai terbaik dari rendemen, viskositas kinematik, densitas, kadar air, bilangan asam, bilangan iod, titik nyala, serta angka setana secara berturut-turut adalah $16,08 \% ; 2,69 \mathrm{~mm}^{2} / \mathrm{s} ; 872,27$ $\mathrm{g} / \mathrm{cm}^{3} ; 0,22 \% ; 0,27 \mathrm{mg} \mathrm{KOH} / \mathrm{g}$ minyak; $17,83 \mathrm{~g}-\mathrm{I}_{2} / 100 \mathrm{~g}$ minyak; $288,33^{\circ} \mathrm{C}$; dan 71,50 .
\end{abstract}

Kata Kunci: Biodiesel, kemiri sunan, destilasi fraksinasi

\begin{abstract}
Biodiesel is an alternative fuel derived from vegetable oils. Philippine tung (Reutealis trisperma) is one of the natural resources that has potential as a material for biodiesel. It is necessary to increase the fatty acid ester components that are relevant to improve the quality of biodiesel. This can be done through fractional distillation. This study aimed to determine the effect of fractional destilation temperature on the quality of the biodiesel, to find out the best fraction of the biodiesel produced and the quality of Philippine tung biodiesel. This study used experimental method with descriptive analysis (3 replications). Fractional distillation was carried out in three temperatures; $A=260-330^{\circ} \mathrm{C} ; B=330-348^{\circ} \mathrm{C}$; and $\mathrm{C}=348-360^{\circ} \mathrm{C}$. The results showed that the biodiesel was distilled through treatment $A$ and $B$. The best biodiesel fraction when viewed from the engine's and the process' requirements was fraction obtained from treatment $A$. The best value of yield, kinematic viscosity, density, moisture content, acid number, iodine number, flash point and cetane number were $16.08 \% ; 2.69 \mathrm{~mm}^{2} / \mathrm{s} ; 872.27 \mathrm{~g} / \mathrm{cm}^{3} ; 0.22 \% ; 0.27 \mathrm{mg} \mathrm{KOH} / \mathrm{g}$ oil; $17.83 \mathrm{~g}-\mathrm{I} / 100 \mathrm{~g}$ oil; $288.33^{\circ} \mathrm{C}$; and 71.50 respectively.
\end{abstract}

Keywords: Biodiesel, Phillipine tung, fractional distillation

Diterima: 2 Februari 2017; Disetujui: 28 Desember 2018

DOI : 10.24198/jt.vol12n2.5

\section{PENDAHULUAN}

Di Indonesia, ketergantungan terhadap bahan bakar fosil terutama minyak bumi masih tinggi, yaitu sebesar $96 \%$ (minyak bumi $48 \%$, gas
$18 \%$, dan batu bara 30\%) dari total konsumsi energi nasional. Konsumsi energi di Indonesia mengalami pertumbuhan rata-rata $5,5 \%$ per 
tahun. Dari tahun 2003 hingga 2013, konsumsi energi final di Indonesia meningkat dari 79 juta Tonne of Oil Equivalent (TOE) menjadi 134 juta TOE (Dewan Energi Nasional, 2014). Peningkatan konsumsi energi yang terus menerus terjadi mengakibatkan persediaan dari energi atau bahan bakar fosil yang tidak dapat diperbarui terus berkurang.

Selain jumlahnya yang terbatas, penggunaan bahan bakar fosil juga berpotensi dapat membahayakan lingkungan. Polutan yang dihasilkan dari pembakaran fosil seperti hidrokarbon $(\mathrm{HC})$, nitrogen oksida $\left(\mathrm{NO}_{\mathrm{x}}\right)$, dan karbon monoksida (CO) merupakan senyawa terbesar yang menyebabkan timbulnya asap, hujan asam, pemanasan global, dan perubahan iklim (Astra, 2010). Hal tersebut memicu munculnya berbagai masalah, seperti keseimbangan ekosistem yang terganggu serta masalah kesehatan. Oleh karena itu, perlu dilakukan pengembangan energi alternatif terbarukan pengganti bahan bakar fosil.

Salah satu bentuk energi alternatif terbarukan yang dapat mengganti bahan bakar fosil adalah biodiesel. Biodiesel merupakan bahan bakar alternatif dari sumber terbarukan yang berasal dari minyak nabati. Minyak nabati mengandung trigliserida yang dapat digunakan sebagai bahan bakar alternatif biodiesel melalui reaksi esterifikasi dan transesterifikasi (Joelianingsih dkk., 2006).

Biodiesel memiliki karakteristik yang hampir sama dengan minyak diesel yang berasal dari fosil (Knothe et al., 2005). Namun, jika dibandingkan dengan diesel atau solar, biodiesel memiliki sifat yang lebih ramah terhadap lingkungan. Hal ini dikarenakan biodiesel dapat terdegradasi dengan mudah (biodegradable) dan menghasilkan emisi gas buang yang lebih baik; bebas sulfur, bilangan asap rendah, efisiensi pembakaran baik, dapat terbakar sempurna, dan tidak menghasilkan racun (Hambali dkk., 2006).

Indonesia memiliki potensi yang besar terhadap pengembangan biodiesel. Kondisi alam Indonesia yang memiliki beraneka ragam tanaman mendukung ketersediaan bahan baku nabati yang digunakan dalam pembuatan biodiesel, seperti kelapa sawit, jarak pagar, kemiri sunan, dan lain-lain. Ketersediaan aneka ragam tanaman yang ada di Indonesia patut untuk dimanfaatkan semaksimal mungkin, terlebih jika dapat dijadikan sebagai solusi dari sebuah permasalahan yang cukup besar seperti ketersediaan energi.
Kemiri sunan merupakan salah satu tanaman yang memiliki potensi sebagai bahan baku biodiesel. Selain banyak ditemukan di Indonesia, rendemen minyak kasar yang dihasilkan dari kernel (daging) kemiri sunan dapat mencapai 45-50\% (Herman dkk., 2013) dan rendemen biodiesel dapat mencapai 41,04$61,1 \%$ dari minyak kasar (Nurjanah et al., 2015). Keunggulan lain dari kemiri sunan sebagai bahan baku biodiesel adalah kemiri sunan sunan tidak dapat dijadikan sebagai bahan pangan karena mengandung asam $\alpha$-oleostearat yang beracun bagi manusia. Sehingga, apabila digunakan sebagai bahan baku biodiesel tidak akan mengganggu kebutuhan masyarakat terhadap bahan pangan.

Pembuatan biodiesel dilakukan melalui proses reaksi kimia transesterifikasi pada minyak nabati atau lemak hewani. Dalam reaksi transesterifikasi, digunakan katalis (pada umumnya katalis basa) dengan alkohol untuk menghasilkan alkil ester asam lemak (Knothe et al., 2005). Biodiesel yang dihasilkan dari proses transesterifikasi mengandung bermacam-macam komponen asam lemak ester. Komponen asam lemak ester serta zat pengotor menentukan mutu dari biodiesel yang dihasilkan, seperti kestabilan oksidasi, viskositas kinematik, emisi yang dihasilkan, angka setana, dan energi yang dihasilkan (Yang et al., 2013).

Knothe (2008) menyatakan bahwa komponen asam lemak ester yang paling sering ditemukan dalam biodiesel adalah asam palmitat, asam stearat, asam oleat, asam linoleat, dan asam linolenat. Penelitian yang telah dilakukan oleh Knothe (2008) menyatakan bahwa angka setana yang dimiliki oleh metil palmitat memiliki nilai paling besar yaitu 85,9. Sedangkan nilai titik leleh yang paling rendah dimiliki oleh metil linolenat $\left(-52^{\circ} \mathrm{C}\right)$, viskositas kinematik $40^{\circ} \mathrm{C}$ terendah dimiliki oleh metil linolenat $\left(3,14 \mathrm{~mm}^{2} / \mathrm{s}\right)$, dan panas pembakaran terbesar dimiliki oleh metil oleat $(11.887,13$ $\mathrm{kJ} / \mathrm{mol}$ ).

Di sisi lain, berdasarkan Keputusan Direktur Jenderal Minyak dan Gas Bumi No. 978.K/10/DJM.S/2013, bahan bakar minyak solar 48 yang beredar di pasaran memiliki standar nilai angka setana $>48$, nilai viskositas kinematik pada $40^{\circ} \mathrm{C}$ sebesar $2,0-4,5 \mathrm{~mm}^{2} / \mathrm{s}$. Dalam produksi biodiesel, hasil yang dihasilkan sebaiknya memiliki sifat fisiko-kimia yang menyerupai sifat bahan bakar solar. Untuk itu, apabila dibandingkan, hasil penelitian Knothe 
(2008) menunjukkan bahwa terdapat metil ester asam lemak yang memiliki sifat fisiko-kimia sesuai dengan standar sifat bahan bakar solar, yaitu metil palmitat serta metil oleat.

Untuk mendapatkan mutu biodiesel yang optimum, maka perlu dilakukan peningkatan komponen asam lemak ester yang relevan terhadap peningkatan mutu biodiesel. Metode yang dapat dilakukan yaitu dengan cara destilasi fraksinasi agar dapat meningkatkan konsentrasi komponen yang diinginkan.

Proses destilasi fraksinasi merupakan suatu metode untuk memisahkan komponenkomponen yang terdapat dalam suatu campuran sehingga terbentuk beberapa fraksi. Proses ini dilakukan berdasarkan nilai titik didih dari komponen tersebut (Ramsden, 2012). Destilasi fraksinasi dapat dilakukan dalam pemisahan komponen yang memiliki titik didih berdekatan dan dapat digunakan untuk memisahkan bermacam-macam komponen sekaligus dalam satu kali operasi (Lister dan Renshaw, 2000).

Dalam proses destilasi fraksinasi, terdapat variabel-variabel penting yang memengaruhi fraksi yang dihasilkan seperti temperatur, tekanan, panjang kolom destilasi, serta refluks (Gilbert dan Martin, 2010). Namun demikian, kajian proses destilasi fraksinasi pada biodiesel khususnya biodiesel kemiri sunan yang dapat memberikan hasil yang optimum masih belum diketahui secara pasti. Oleh karena itu, perlu dilakukan penelitian mengenai kajian proses destilasi fraksinasi pada biodiesel kemiri sunan agar diperoleh fraksi yang memiliki rendemen dan mutu optimal.

Pada penelitian pendahuluan, telah dilakukan percobaan dalam penentuan temperatur yang akan digunakan dalam penelitian utama. Dari temperatur destilasi yang digunakan, akan terbentuk fraksi-fraksi biodiesel yang akan diuji pada penelitian utama. Pengujian mutu yang dilakukan yaitu viskositas kinematik, densitas, kadar air, bilangan asam, bilangan iod, titik nyala, dan angka setana sehingga dapat diketahui fraksi dengan kandungan jenis metil ester yang manakah yang memiliki mutu terbaik.

\section{METODE PENELITIAN}

\section{Bahan dan Alat}

Bahan baku yang digunakan pada penelitian ini adalah minyak kemiri sunan, metanol, $\mathrm{H}_{2} \mathrm{SO}_{4}, \mathrm{KOH}$, dan aquades. Sedangkan bahan kimia yang digunakan untuk analisa mutu adalah indikator pp, $\mathrm{KOH} 0,1 \mathrm{~N}, \mathrm{Na}_{2} \mathrm{~S}_{2} \mathrm{O}_{3} 0,1 \mathrm{~N}$, asam oksalat $0,1 \mathrm{~N}$, kloroform, larutan Wijs, larutan KI $15 \%$, pati $1 \%$, etanol.

Alat-alat yang digunakan pada penelitian ini antara lain beaker glass, labu erlenmeyer, gelas ukur, labu ukur, hotplate stirrer, corong pisah, timbangan, termometer, pipet, labu destilasi, receiver, kondensor, heating mantle, oven, piknometer, viskometer Ostwald, dan buret.

\section{Metode}

Metode yang digunakan adalah metode eksperimen dengan analisis deskriptif. Terdapat 3 taraf perlakuan suhu destilasi fraksinasi yang diterapkan, yaitu perlakuan $\mathrm{A}=260-330^{\circ} \mathrm{C} ; \mathrm{B}=$ $330-348^{\circ} \mathrm{C} ;$ dan $\mathrm{C}=348-360^{\circ} \mathrm{C}$. Percobaan diulang sebanyak tiga kali. Tahapan penelitian terdiri dari karakterisasi minyak kemiri sunan, pembuatan biodiesel (esterifikasi, transesterifikasi, destilasi fraksinasi), dan analisis mutu biodiesel kemiri sunan. Pada proses destilasi fraksinasi, rasio refluks yang digunakan adalah 2:1, dioperasikan pada tekanan $10 \mathrm{mmHg}$ dan panjang kolom $45 \mathrm{~cm}$. Sementara itu, analisis mutu biodiesel meliputi parameter rendemen, viskositas kinematik, densitas, kadar air, bilangan asam, bilangan iod, titik nyala, dan angka setana. Gambar 1 menyajikan diagram alir tahapan yang dilakukan pada penelitian ini.

\section{HASIL DAN PEMBAHASAN}

\section{Karakteristik Minyak Kemiri Sunan}

Pengujian karakteristik minyak kemiri sunan dilakukan untuk mengetahui kondisi awal minyak kemiri sunan yang digunakan sebagai bahan baku serta perubahan yang terjadi pada proses pembuatan biodiesel kemiri sunan. Karakteristik minyak kemiri sunan yang diuji disajikan pada Tabel 1.

Tabel 1. Karakteristik Minyak Kemiri Sunan

\begin{tabular}{llc}
\hline \multicolumn{1}{c}{ Parameter } & \multicolumn{1}{c}{ Satuan } & Nilai \pm SD \\
\hline $\begin{array}{l}\text { Viskositas Kinematik } \\
\left(40^{\circ} \mathrm{C}\right)\end{array}$ & $\mathrm{mm}^{2} / \mathrm{s}$ & $39,69 \pm 0,01$ \\
$\begin{array}{l}\text { Densitas }\left(25^{\circ} \mathrm{C}\right) \\
\text { Kadar air }\end{array}$ & $\mathrm{kg} / \mathrm{m}^{3}$ & $933,27 \pm 0,46$ \\
Bilangan asam & $\%-\mathrm{wb}$ & $0,25 \pm 0,00$ \\
& $\mathrm{mg} \mathrm{KOH} / \mathrm{g}$ & $15,33 \pm 0,47$ \\
Kadar FFA & minyak & \\
Bilangan iod & $\%$ & $7,58 \pm 0,23$ \\
& $\mathrm{~g} \mathrm{I} / 100 \mathrm{~g}$ & $16,71 \pm 0,48$ \\
& minyak & \\
\hline
\end{tabular}




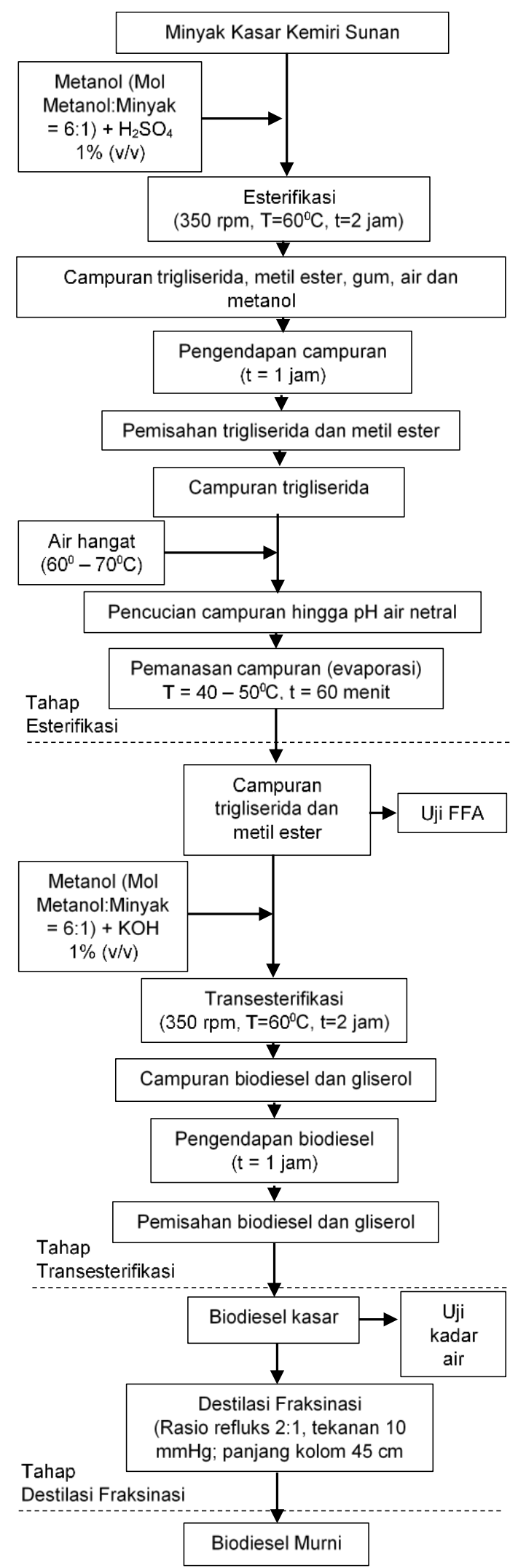

Gambar 1. Diagram Alir Tahapan Penelitian

Nilai viskositas kinematik yang diperoleh dari hasil pengujian minyak kemiri sunan yaitu sebesar $39,70 \mathrm{~mm}^{2} / \mathrm{s}$. Menurut Knothe et al. (2005), semakin panjang rantai karbon yang dimiliki oleh asam lemak penyusun suatu minyak, maka semakin tinggi viskositas minyak tersebut. Viskositas yang tinggi dapat disebabkan oleh kandungan asam lemak yang terdapat di dalam minyak, dimana kandungan asam lemak metil linolenat dan linoleat yang memiliki rantai karbon yang panjang merupakan dua asam lemak dengan kandungan terbesar di dalam minyak kemiri sunan yang digunakan.

Nilai densitas yang diperoleh pada minyak kemiri sunan yaitu sebesar $933,60 \mathrm{~kg} / \mathrm{m}^{3}$. Nilai densitas kemiri sunan dipengaruhi oleh komponen asam lemak yang menjadi penyusun minyak. Semakin jenuh minyak, maka semakin rendah densitas minyak tersebut (Altun et al., 2010).

Nilai kadar air yang terdapat di dalam minyak kemiri sunan berdasarkan hasil dari pengujian yaitu sebesar 0,25\%-wb. Kadar air yang tinggi dapat mempersulit proses produksi biodiesel terutama pada proses transesterifikasi. Keberadaan kadar air yang tinggi dapat meningkatkan terjadinya reaksi saponifikasi dan mengurangi konversi trigliserida menjadi FAME yang terjadi sehingga menurunkan rendemen yang dihasilkan (Atadashi et al., 2012). Selain itu, kadar air yang tinggi juga dapat mempercepat hidrolisis yang terjadi pada minyak. Pengecilan ukuran yang dilanjutkan dengan proses penyangraian dan pengeringan biji kemiri sunan dapat menjadi alternatif untuk mengurangi kadar air pada minyak.

Dari hasil pengujian, diperoleh nilai bilangan asam yang terdapat dalam minyak kemiri sunan yaitu sebesar $15,23 \mathrm{mg} \mathrm{KOH/g}$ minyak. Bilangan asam tersebut masih tergolong sangat tinggi untuk dijadikan biodiesel. Bilangan asam yang tinggi mengindikasikan banyaknya asam lemak bebas yang terdapat di dalam minyak tersebut. Hal ini terbukti karena kadar asam lemak bebas atau FFA yang diperoleh dalam minyak kemiri sunan masih tergolong tinggi.

Hasil pengujian kadar FFA yang dilakukan menunjukkan bahwa kadar FFA yang dimiliki oleh minyak kemiri sunan yaitu sebesar $7,59 \%$. Persentase tersebut masih tergolong tinggi untuk proses transesterifikasi karena besarnya melebihi batas yang disyaratkan, yakni $3 \mathrm{mg}$ KOH/g-minyak (Pranowo dkk., 2014) atau di atas 2\% (Romano dan Sorichetti, 2011). Oleh karena itu, dilakukan proses esterifikasi terlebih dahulu untuk menurunkan kadar FFA yang terdapat pada minyak. Proses esterifikasi yang dilakukan berhasil menurunkan kadar FFA minyak kemiri sunan menjadi sebesar rata-rata $0,54 \%$. 
Kadar FFA yang diturunkan dapat mengurangi kemungkinan terbentuknya sabun ketika minyak bereaksi dengan katalis pada proses transesterifikasi. Sehingga, proses transesterifikasi akan berjalan lebih efisien. Penurunan kadar FFA pada proses esterifikasi juga disebabkan konversi asam lemak bebas yang berberat molekul tinggi menjadi metil ester yang berberat molekul lebih rendah (Djenar dan Lintang, 2012).

Bilangan iod yang dimiliki oleh minyak kemiri sunan yaitu sebesar $16,75 \mathrm{~g} \mathrm{l} / 100 \mathrm{~g}$ minyak. Bilangan iod menunjukkan jumlah asam lemak tak jenuh yang berada di dalam minyak yang diuji. Bilangan iod pada minyak kemiri sunan menunjukkan bahwa minyak tersebut tidak mudah untuk teroksidasi sehingga bersifat baik dalam aspek penyimpanan.

\section{Proses Produksi Biodiesel}

\section{Proses Produksi Biodiesel Kasar}

Proses pembuatan biodiesel kasar dilakukan melalui proses esterifikasi dan transesterifikasi. Masing-masing pembuatan dilakukan dengan bahan baku minyak kemiri sunan sebanyak 400 $\mathrm{mL}$. Proses pembuatan dilakukan sebanyak tiga kali dikarenakan keterbatasan kapasitas alat atas jumlah biodiesel yang ingin dibuat.

Sampel biodiesel kasar yang dihasilkan kemudian diukur kadar airnya sebagai pengujian keseragaman sebelum dilakukan proses destilasi fraksinasi. Hasil pengujian menunjukkan bahwa kadar air sampel biodiesel kasar yang dihasilkan memiliki nilai yang tidak berbeda jauh antara satu dengan yang lainnya yaitu rata-rata 24,05 \pm 2,26 \%-wb. Sampel yang dihasilkan kemudian dicampur dan diaduk rata hingga homogen sebelum dilakukan perlakuan destilasi fraksinasi. Pencampuran ini dilakukan agar sampel yang digunakan pada destilasi fraksinasi memiliki mutu yang sama. Sampel yang dicampurkan kemudian diuji kadar air nya kembali dan diperoleh nilai kadar air sebesar 26,52\%-wb.

Setelah dicampurkan, sampel kemudian dibagi rata menjadi enam sampel dengan jumlah yang sama yaitu sebanyak $142 \pm 2 \mathrm{~g}$ atau setara dengan $167 \pm 3 \mathrm{~mL}$. Sampel yang dihasilkan digunakan untuk tiga kali pengulangan proses destilasi fraksinasi dengan setiap ulangan dibagi menjadi dua kali proses destilasi. Sehingga total proses destilasi fraksinasi yang dilakukan yaitu sebanyak enam kali.

Pembagian proses destilasi fraksinasi menjadi dua kali pada setiap ulangan dikarenakan apabila sampel yang digunakan melebihi $200 \mathrm{~mL}$, maka proses destilasi fraksinasi tidak dapat dijalankan.

\section{Rendemen Biodiesel Kasar}

Rendemen proses pembuatan biodiesel kemiri sunan terdiri dari rendemen esterifikasi, rendemen transesterifikasi, serta total proses pembuatan. Rendemen esterifikasi merupakan rendemen yang dihasilkan dari bahan baku minyak kemiri sunan hingga proses esterifikasi selesai. Rendemen proses pemisahan, proses pencucian, serta proses evaporasi merupakan termasuk dari bagian rendemen esterifikasi. Rendemen esterifikasi yang diperoleh yaitu sebesar $93,89 \%$.

Rendemen pemisahan merupakan rendemen yang dihasilkan dari bahan baku minyak kemiri sunan hingga minyak yang dihasilkan dari proses pemisahan. Rendemen pemisahan pada esterifikasi diperoleh sebesar $106,33 \%$. Rendemen pencucian merupakan rendemen yang dihasilkan dari minyak hasil pemisahan hingga minyak yang dihasilkan dari proses pencucian. Rendemen pencucian pada esterifikasi diperoleh sebesar $91,76 \%$. Rendemen evaporasi merupakan rendemen yang dihasilkan dari minyak hasil pencucian hingga minyak yang dihasilkan dari proses evaporasi. Rendemen pemisahan pada esterifikasi diperoleh sebesar $93,89 \%$

Nilai rendemen pemisahan yang tinggi menandakan bahwa terdapat metanol atau zat pengotor lainnya yang masih tercampur ke dalam minyak yang telah dipisahkan. Sehingga menyebabkan nilai rendemen pemisahan melebihi nilai $100 \%$. Zat pengotor yang terdapat di dalam minyak kemudian dipisahkan menggunakan metode pencucian.

Rendemen pencucian yang lebih kecil dibandingkan dengan rendemen pemisahan menandakan bahwa zat pengotor yang terdapat pada minyak hasil transesterifikasi sudah terbawa oleh air yang digunakan dalam pencucian. Air yang digunakan pada proses pencucian menyebabkan kadar air dalam minyak meningkat, sehingga perlu dilakukan proses evaporasi. Rendemen evaporasi yang lebih rendah dibandingkan dengan rendemen pencucian mengindikasikan bahwa terdapat air yang berhasil teruapkan akibat proses pemanasan yang diberikan.

Minyak hasil esterifikasi kemudian dilakukan proses transesterifikasi. Rendemen transesterifikasi yang diperoleh yaitu sebesar 
96,12\%. Rendemen transesterifikasi yang dimaksud sama dengan rendemen pemisahan hasil transesterifikasi. Nilai rendemen yang tinggi diperoleh karena tidak dilakukan pencucian dan evaporasi terhadap biodiesel kasar yang diperoleh. Sehingga, tidak terjadi pengurangan massa akibat kehilangan zat pengotor yang terdapat dalam biodiesel kasar. Rendemen total merupakan rendemen yang dihasilkan dari bahan baku minyak kemiri sunan hingga minyak yang dihasilkan dari proses transesterifikasi. Rendemen total pembuatan biodiesel kasar yang diperoleh yaitu sebesar $88,79 \%$.

\section{Rendemen Destilasi Fraksinasi}

Rendemen proses destilasi fraksinasi biodiesel merupakan rendemen yang dihasilkan dari biodiesel kasar hasil transesterifikasi hingga proses destilasi fraksinasi selesai. Rendemen terdiri dari rendemen perlakuan A (fraksi destilasi pertama), rendemen perlakuan B (fraksi destilasi kedua), serta rendemen perlakuan $C$ (fraksi destilasi ketiga). Hasil perhitungan rendemen proses destilasi fraksinasi biodiesel yang diperoleh yaitu $16,08 \% \pm 0,59$ pada perlakuan $A, 12,10 \% \pm 1,12$ pada perlakuan $B$, dan $0 \% \pm 0,00$ pada perlakuan $C$ seperti yang disajikan pada Gambar 2.

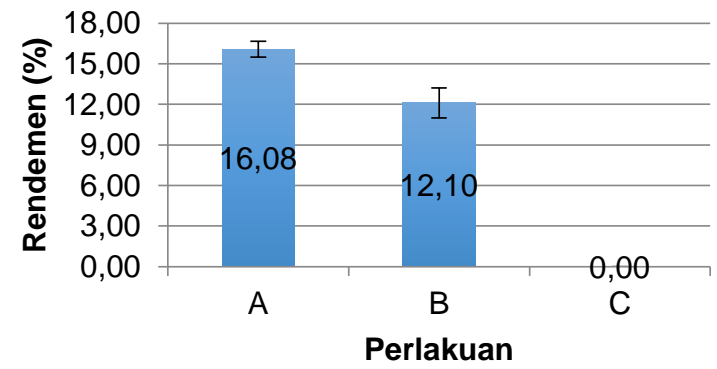

Gambar 2. Grafik Rendemen Biodiesel

Rendemen perlakuan A memiliki nilai yang lebih besar dibandingkan dengan rendemen perlakuan B dan C. Hal ini diduga karena komponen dengan titik didih $260-330^{\circ} \mathrm{C}$ seperti metil palmitat yang terdapat di dalam biodiesel kasar lebih banyak yang berhasil terdestilasi. Pada perlakuan $\mathrm{C}$ tidak terjadi destilasi fraksinasi biodiesel diduga karena temperatur perlakuan yang terlalu tinggi. Hasil yang diperoleh menunjukkan bahwa sampel biodiesel yang dihasilkan diduga tidak memiliki kandungan metil ester yang mempunyai titik didih melebihi $348^{\circ} \mathrm{C}$, seperti metil oleat dan metil linolenat.

Bahan baku minyak kemiri sunan memiliki komponen asam linolenat (41,09\%), asam linoleat $(17,05 \%)$, asam oleat $(14,48 \%)$, dan asam palmitat (12,49\%). Menurut Cermak et al. (2007), komposisi asam lemak dari suatu minyak dipengaruhi oleh bahan baku yang digunakan. Sehingga, seharusnya perlakuan C memiliki rendemen yang lebih besar karena minyak kemiri sunan yang digunakan memiliki komponen metil linolenat yang besar. Rendemen perlakuan $C$ yang rendah dapat dikarenakan sampel yang terlalu banyak pada proses destilasi fraksinasi, panjang kolom yang terlalu pendek, atau laju pemanasan yang terlalu rendah.

\section{Rendemen Total Biodiesel}

Rendemen total biodiesel merupakan rendemen yang dihasilkan dari minyak kemiri sunan hingga proses destilasi fraksinasi selesai. Perhitungan nilai rendemen total dilakukan untuk mengetahui besarnya rendemen pengolahan dari awal hingga akhir proses pembuatan biodiesel kemiri sunan. Nilai rendemen total juga dapat digunakan untuk mengukur tingkat efektivitas proses yang digunakan.

Rendemen total yang dihasilkan yaitu $13,53 \% \pm 0,60$ pada perlakuan $A, 10,18 \% \pm 0,88$ pada perlakuan $B$, dan $0 \%$ pada perlakuan $C$ seperti yang disajikan pada Gambar 3.

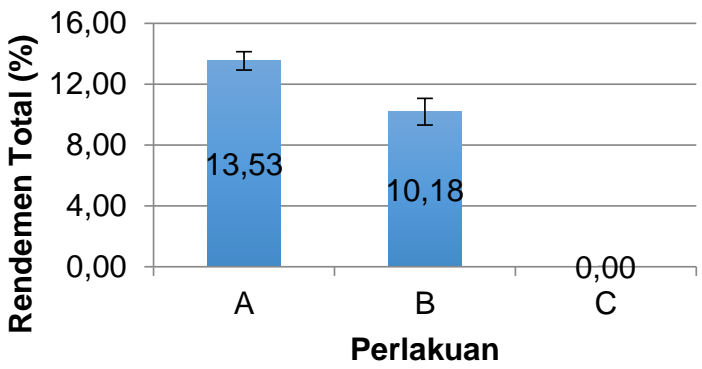

Gambar 3. Grafik Rendemen Total Biodiesel

\section{Analisis Mutu Biodiesel Kemiri Sunan}

\section{Viskositas Kinematik}

Viskositas kinematik merupakan kemampuan bahan bakar untuk melawan pergerakan relatif dari lapisan penyusunnya karena daya tarik yang terjadi antar molekul. Viskositas kinematik merupakan sifat yang penting karena memengaruhi tingkat kemudahan nyala mesin, kualitas penyemprotan, serta kualitas dari pembakaran (Barabas dan Todorut, 2011).

Nilai viskositas kinematik yang dihasilkan sudah memenuhi nilai SNI 7182:2015 yaitu sebesar 2,3-6,0 $\mathrm{mm}^{2} / \mathrm{s}$. Nilai viskositas kinematik 
yang diperoleh pada biodiesel kemiri sunan adalah $2,69 \pm 0,16 \mathrm{~mm}^{2} / \mathrm{s}$ pada perlakuan $A$ dan $2,99 \pm 0,13 \mathrm{~mm}^{2} / \mathrm{s}$ pada perlakuan B seperti yang ditunjukkan pada Gambar 4. Nilai yang diperoleh sudah memenuhi syarat mutu biodiesel SNI 7182:2015.

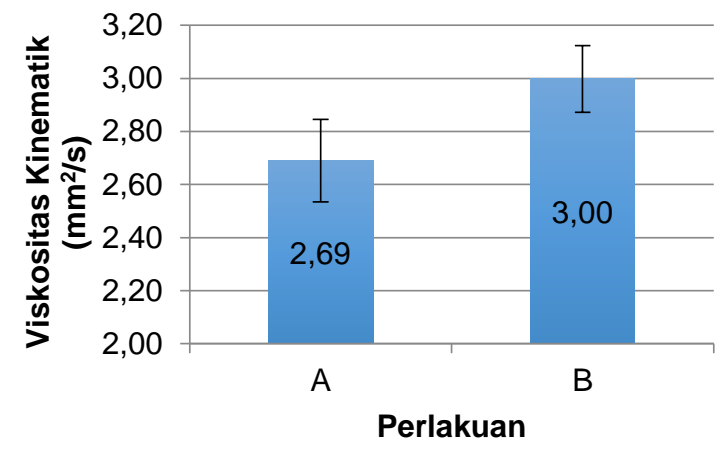

Gambar 4. Grafik Viskositas Kinematik Biodiesel

Nilai viskositas kinematik perlakuan A lebih rendah dibandingkan dengan perlakuan $\mathrm{B}$. Hal ini diduga karena sampel perlakuan A memiliki rantai karbon yang lebih pendek dibandingkan dengan sampel perlakuan B (Knothe et al., 2005). Hal ini dikarenakan semakin besar molekul hidrokarbon, maka area kontak antar molekul lebih besar. Sehingga memungkinkan terjadinya gaya tarik menarik antar molekul semakin banyak terjadi dan menyebabkan viskositas semakin besar.

Hal ini dibuktikan dengan perlakuan yang diberikan, dimana pada perlakuan A temperatur destilasi yang digunakan mengacu kepada titik didih metil palmitat sedangkan temperatur yang diberikan pada perlakuan B mengacu kepada titik didih metil linoleat. Pada hasil GC-MS yang dilakukan, komponen sampel perlakuan A memiliki konsentrasi metil palmitat yang paling tinggi yaitu $24,26 \%$. Sedangkan komponen sampel perlakuan B memiliki konsentrasi metil linoleat yang paling tinggi yaitu $36,03 \%$. Metil palmitat memiliki rantai karbon yang lebih pendek dibandingkan dengan metil linoleat. Sifat tersebut diduga memengaruhi viskositas kinematik perlakuan A menjadi lebih rendah dibandingkan dengan perlakuan $\mathrm{B}$.

Nilai viskositas kinematik biodiesel yang diperoleh berbeda jauh apabila dibandingkan dengan nilai viskositas kinematik minyak kemiri sunan. Viskositas memiliki hubungan yang erat dengan komposisi asam lemak yang terkandung dalam minyak. Viskositas biodiesel yang lebih rendah dibandingkan dengan bahan bakunya diduga karena perubahan panjang rantai asam lemak yang menjadi semakin pendek akibat proses esterifikasi dan transesterifikasi (Djenar dan Lintang, 2012).

Nilai viskositas perlakuan A yang lebih rendah mengindikasikan bahwa biodiesel perlakuan A memiliki kualitas proses injeksi dan atomisasi yang lebih baik dibandingkan dengan perlakuan B. Hal ini dikarenakan semakin tinggi viskositas bahan bakar maka diameter tetesan bahan bakar dari injektor semakin besar. (Holilah dkk., 2013). Diameter tetesan bahan bakar yang besar akan mempersulit distribusi bahan bakar pada sistem bahan bakar sehingga menyebabkan pembakaran yang lebih buruk.

\section{Densitas}

Densitas merupakan salah satu karakteristik penting pada bahan bakar yang digunakan. Densitas bahan bakar dapat memengaruhi kualitas dari atomisasi dan pembakaran yang terjadi pada mesin. Densitas juga memengaruhi nilai angka setana, viskositas, serta nilai kalor dari bahan bakar (Barabas dan Todorut, 2011).

Densitas biodiesel pada temperatur $40^{\circ} \mathrm{C}$ yang ditentukan pada syarat mutu biodiesel SNI $7182: 2015$ memiliki nilai $850-890 \mathrm{~kg} / \mathrm{m}^{3}$. Nilai densitas sampel biodiesel yang diperoleh adalah $872,27 \pm 3,47 \mathrm{~kg} / \mathrm{m}^{3}$ pada perlakuan $A$ dan $882,43 \pm 1,26 \mathrm{~kg} / \mathrm{m}^{3}$ pada perlakuan B seperti yang disajikan pada Gambar 5 .

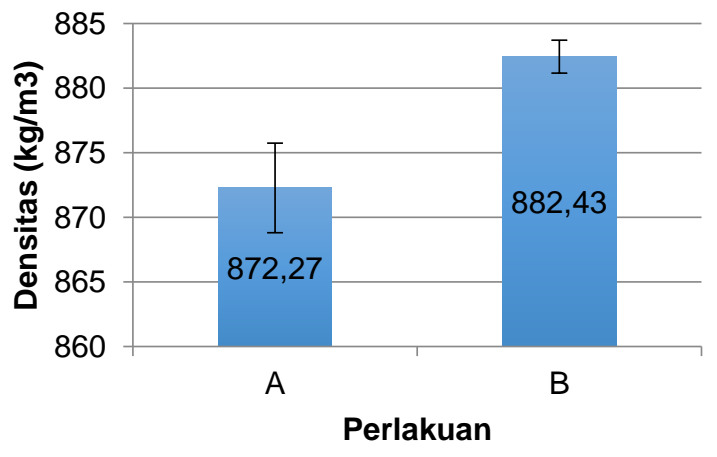

Gambar 5. Grafik Densitas Biodiesel

Nilai densitas pada bahan bakar bergantung kepada komposisi asam lemak pada minyak serta tingkat kejenuhan dari asam lemak tersebut. Semakin jenuh ester yang terkandung dalam sampel, maka semakin rendah densitas sampel tersebut (Altun et al., 2010). Nilai densitas biodiesel pada perlakuan $A$ yang lebih kecil dibandingkan dengan perlakuan $B$ diduga karena sampel perlakuan $A$ memiliki komponen ester yang lebih jenuh. Dalam penelitian ini dibuktikan dengan hasil pengujian bilangan iod serta temperatur perlakuan yang digunakan. Temperatur perlakuan A yang mengacu kepada 
titik didih metil palmitat merupakan asam lemak jenuh sedangkan metil linoleat yang titik didihnya dijadikan acuan pada perlakuan B merupakan asam lemak tak jenuh.

Densitas yang dihasilkan dari sampel biodiesel kemiri sunan lebih rendah dibandingkan dengan densitas bahan minyak kemiri sunan yang digunakan. Proses esterifikasi dan transesterifikasi yang dilakukan menyebabkan asam lemak yang terdapat pada minyak kemiri sunan dikonversi menjadi senyawa ester (metil ester) sehingga menyebabkan nilai densitas menurun (Djenar dan Lintang, 2012).

Hasil densitas perlakuan A mengindikasikan bahwa sampel perlakuan A memiliki kualitas atomisasi yang lebih baik dibandingkan dengan perlakuan B. Hal ini dikarenakan perlakuan B memiliki densitas lebih tinggi sehingga diameter tetesan bahan bakar yang dihasilkan juga semakin besar dan menghambat proses atomisasi (Holilah dkk., 2013). Diameter tetesan bahan bakar yang besar dapat mengurangi jumlah bahan bakar yang terbakar pada proses pembakaran. Menurut Barabas dan Todorut (2011), semakin jenuh asam lemak, maka semakin tinggi panas pembakaran dalam satuan massa $(\mathrm{kJ} / \mathrm{kg})$. Akan tetapi, karena asam lemak jenuh memiliki densitas yang rendah maka panas pembakaran dalam satuan volume $(\mathrm{kJ} / \mathrm{L})$ yang dimiliki lebih rendah dibandingkan asam lemak tak jenuh. Panas pembakaran penting dalam mengindikasikan jumlah energi yang dihasilkan.

\section{Kadar Air}

Kadar air dalam biodiesel merupakan sifat yang menunjukkan potensi masalah yang terdapat di dalam biodiesel tersebut. Keberadaan air dapat menyebabkan percepatan reaksi hidrolisis dan mempercepat pertumbuhan mikroba di dalam nya (Atadashi et al., 2012). Keberadaan air juga dapat meningkatkan kadar FFA yang dapat menyebabkan korosi pada sistem pembakaran (Barabas dan Todorut, 2011).

Nilai kadar air yang dimiliki oleh sampel biodiesel kemiri sunan yang ditetapkan pada syarat mutu SNI 7182:2015 yaitu memiliki nilai maksimum sebesar 0,05\%. Nilai kadar air yang diperoleh dari penelitian ini yaitu $0,22 \pm 0,06 \%$ wb pada perlakuan $A$ dan 0,24 $\pm 0,17 \%$-wb pada perlakuan B seperti yang ditunjukkan pada Gambar 6. Nilai kadar air sampel belum memenuhi syarat mutu biodiesel pada SNI 7182:2015.

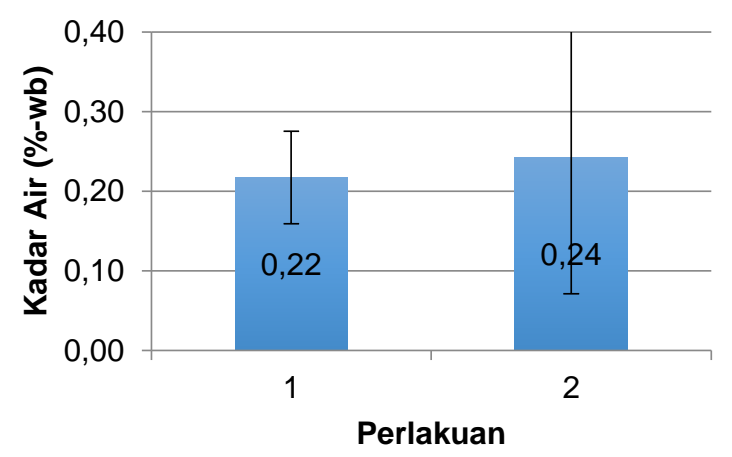

Gambar 6. Grafik Kadar Air Biodiesel

Nilai kadar air yang diperoleh jauh dari batas syarat mutu SNI 7182:2015. Tingginya nilai kadar air yang diperoleh diduga karena pada penelitian ini tidak dilakukan proses pemurnian dan evaporasi. Hal ini menyebabkan masih terdapat banyak kandungan air yang terbawa pada sampel karena terbentuknya air akibat reaksi asam lemak dengan katalis pada proses transesterifikasi (Knothe et al., 2005). Sehingga tidak terjadi penurunan drastis nilai kadar air seperti yang terjadi pada parameter lainnya.

Kadar air yang terdapat dalam biodiesel merupakan sumber utama kontaminasi bahan bakar. Nilai kadar air perlakuan B yang lebih tinggi mengindikasikan bahwa sampel perlakuan B lebih cepat terhidrolisis dibandingkan dengan sampel perlakuan A. Reaksi hidrolisis akan terjadi pada alkil ester yang terkandung di dalam biodiesel dan akan menyebabkan peningkatan kandungan FFA serta mempengaruhi peningkatan bilangan asam (Knothe et al., 2005). Kandungan FFA yang meningkat akibat hidrolisis dapat menyebabkan timbulnya ketengikan. Hal ini dibuktikan dengan sampel biodiesel yang memiliki bau tidak sedap. Selain itu, sampel perlakuan $B$ yang memiliki kadar air lebih tinggi juga akan lebih mudah menyebabkan korosi pada komponen bahan bakar serta pertumbuhan mikroba sehingga mengakibatkan terjadinya penyumbatan sistem bahan bakar (Atadashi et al., 2012).

\section{Bilangan Asam}

Bilangan asam merupakan jumlah $\mathrm{KOH}$ dalam miligram yang diperlukan untuk menetralisasi unsur asam dalam satu gram sampel. Nilai bilangan asam secara langsung mengindikasikan jumlah asam lemak bebas yang ada di dalam sampel, tingkat korosif bahan bakar, serta keberadaan air dalam biodiesel. Nilai bilangan asam juga menunjukkan kesegaran biodiesel yang dihasilkan, dimana biodiesel dengan waktu penyimpanan yang lebih lama 
diduga memiliki nilai bilangan asam yang lebih tinggi (Barabas dan Todorut, 2011).

Nilai bilangan asam yang diperoleh dari biodiesel kemiri sunan adalah 0,27 $\pm 0,03 \mathrm{mg}$ $\mathrm{KOH} / \mathrm{g}$ Minyak pada perlakuan A dan 0,69 $\pm 0,13$ $\mathrm{mg} \mathrm{KOH} / \mathrm{g}$ Minyak pada perlakuan B seperti yang ditunjukkan pada Gambar 7.

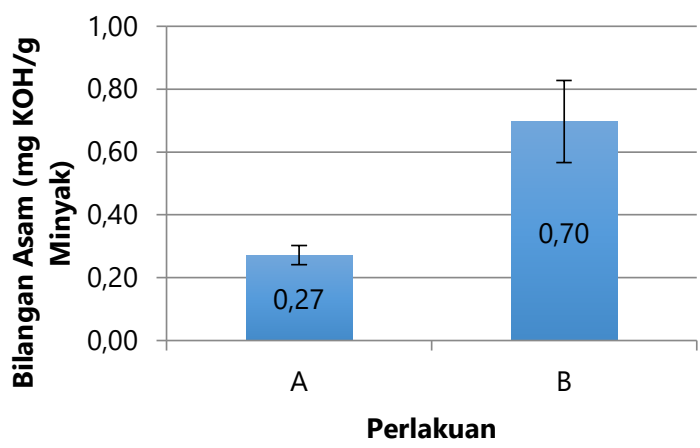

Gambar 7. Grafik Bilangan Asam Biodiesel

Nilai bilangan asam biodiesel yang ditentukan pada syarat mutu SNI 7182:2015 yaitu harus memiliki nilai maksimum $0,5 \mathrm{mg}$ $\mathrm{KOH} / \mathrm{g}$ Minyak. Nilai bilangan asam pada perlakuan A sudah memenuhi syarat SNI yang ditentukan. Sedangkan nilai bilangan asam pada perlakuan $\mathrm{B}$ belum memenuhi syarat SNI yang ditentukan.

Nilai bilangan asam pada perlakuan B yang lebih tinggi dibandingkan dengan bilangan asam pada perlakuan A. Hal ini diduga karena terjadinya hidrolisis dan oksidasi yang lebih cepat pada sampel perlakuan B. Oksidasi yang terjadi pada minyak dapat membentuk asam organik di dalam nya. Sedangkan hidrolisis yang terjadi dapat menyebabkan pembentukan asam lemak bebas sehingga dapat meningkatkan bilangan asam (Barabas dan Todorut, 2011). Hal tersebut dibuktikan dari hasil pengujian bilangan iod dan kadar air dimana sampel perlakuan B memiliki nilai yang lebih tinggi pada dua parameter tersebut.

Nilai bilangan asam yang diperoleh dari sampel biodiesel sangat berbeda jauh dengan nilai bilangan asam bahan baku minyak kemiri sunan. Terjadi penurunan nilai bilangan asam dari 15,23 mg KOH/g minyak menjadi 0,2-0,6 mg $\mathrm{KOH} / \mathrm{g}$ minyak setelah bahan baku mengalami proses pembuatan biodiesel. Penurunan bilangan asam dikarenakan asam lemak bebas yang sebelumnya banyak terkandung dalam minyak kemiri sunan telah bereaksi dengan ion metoksida membentuk ester pada proses transesterifikasi (Kusumaningsih dkk., 2006).
Menurut Sanford et al. (2009), nilai asam yang tinggi dapat menyebabkan korosi pada tangki penyimpanan bahan bakar. Nilai bilangan asam yang diperoleh mengindikasikan bahwa sampel perlakuan B dapat lebih mudah untuk menyebabkan korosi pada tangki penyimpanan. Sehingga apabila ditinjau dari aspek penyimpanan dan transportasi, sampel perlakuan $A$ lebih baik untuk digunakan. Nilai bilangan asam yang meningkat akibat terjadinya reaksi hidrolisis dan oksidasi juga mengakibatkan timbulnya ketengikan. Hal ini menjelaskan ketengikan yang terjadi pada sampel biodiesel yang dihasilkan.

\section{Bilangan lod}

Bilangan iod merupakan salah satu sifat yang paling penting dari karakteristik biodiesel. Bilangan iod merupakan sifat untuk mengukur jumlah dari lemak dan kandungan minyak tak jenuh disampaikan dalam persentase iod yang terabsorpsi. Bilangan iod digunakan untuk memperkirakan kecenderungan bahan bakar untuk teroksidasi serta berpolimerisasi (Knothe et al., 2005).

Nilai bilangan iod yang diperoleh dari biodiesel yang dihasilkan memiliki nilai sebesar $17,83 \pm 1,16 \mathrm{~g} \mathrm{I}_{2} / 100 \mathrm{~g}$ minyak pada perlakuan $\mathrm{A}$ dan 19,96 \pm 2,79 $\mathrm{g} \mathrm{I}_{2} / 100 \mathrm{~g}$ minyak pada perlakuan B seperti yang disajikan pada Gambar 8. Nilai bilangan iod sudah memenuhi syarat SNI 7182:2015 yaitu maksimum sebesar $115 \mathrm{~g} \mathrm{I}_{2} / 100$ g minyak.

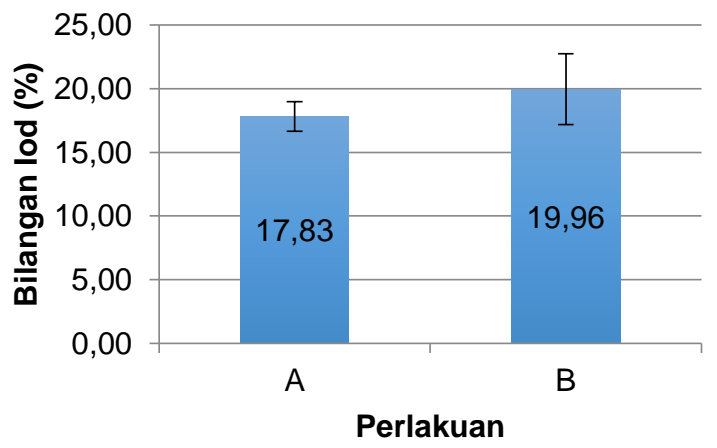

Gambar 8. Grafik Bilangan lod Biodiesel

Nilai bilangan iod yang diperoleh cukup rendah di bawah batas maksimal. Nilai bilangan iod yang rendah menunjukkan bahwa sampel memiliki tingkat kemudahan oksidasi dan polimerisasi yang rendah. Menurut Van Gerpen et al. (2004), semakin tak jenuh komponen asam lemak maka semakin rentan terhadap oksidasi. Ikatan rangkap yang terdapat dalam asam lemak tak jenuh mudah bereaksi dengan oksigen 
sehingga lebih rentan teroksidasi. Ikatan rangkap yang terdapat dalam asam lemak juga lebih rentan terhadap reaksi polimerisasi (Knothe et al., 2005). Hal ini akan menyebabkan peningkatan viskositas dan pembentukan komponen yang tidak mudah larut sehingga dapat menyumbat saluran bahan bakar.

Sampel biodiesel perlakuan B memiliki nilai bilangan iod yang lebih tinggi dibandingkan dengan sampel biodiesel dengan perlakuan $A$. Hal ini diduga terjadi karena sampel perlakuan $B$ memiliki lebih banyak asam lemak tak jenuh sedangkan sampel A memiliki lebih banyak asam lemak jenuh. Hal ini ditunjukkan oleh temperatur destilasi fraksinasi perlakuan B yang mengacu kepada titik didih asam lemak metil linoleat dan metil oleat yang merupakan asam lemak tak jenuh. Sedangkan metil palmitat yang titik didihnya dijadikan acuan sebagai temperatur destilasi perlakuan A merupakan asam lemak jenuh.

Bilangan iod dan keterkaitannya dengan kemampuan biodiesel teroksidasi dan berpolimerisasi berpengaruh terutama pada penyimpanan biodiesel (Knothe et al., 2005). Keberadaan udara pada saat penyimpanan akan menyebabkan biodiesel teroksidasi. Biodiesel sampel A yang memiliki bilangan iod lebih rendah menunjukkan ketahanan terhadap oksidasi yang lebih baik dan tidak mudah membentuk endapan.

\section{Titik Nyala}

Titik nyala merupakan temperatur minimum dimana bahan bakar mulai membentuk api. Titik nyala dari bahan bakar tidak memberikan pengaruh langsung kepada pembakaran. Akan tetapi, titik nyala bahan bakar mengindikasikan tingkat bahaya bahan bakar. Semakin tinggi titik nyala, maka semakin aman bahan bakar dalam aspek penyimpanan dan transportasi.

Nilai titik nyala yang diperoleh dari hasil pembuatan biodiesel kemiri sunan yaitu $265 \pm$ $13,23{ }^{\circ} \mathrm{C}$ pada sampel perlakuan A dan $288,3 \pm$ $2,89{ }^{\circ} \mathrm{C}$ pada sampel perlakuan $\mathrm{B}$ seperti yang ditunjukkan pada Gambar 9. Menurut standar mutu biodiesel yang telah ditetapkan pada SNI 7182:2015, batas nilai titik nyala yaitu memiliki nilai melebihi dari $100^{\circ} \mathrm{C}$. Hasil pengukuran titik nyala biodiesel kemiri sunan diperoleh bahwa sudah memenuhi syarat mutu SNI 7182:2015.

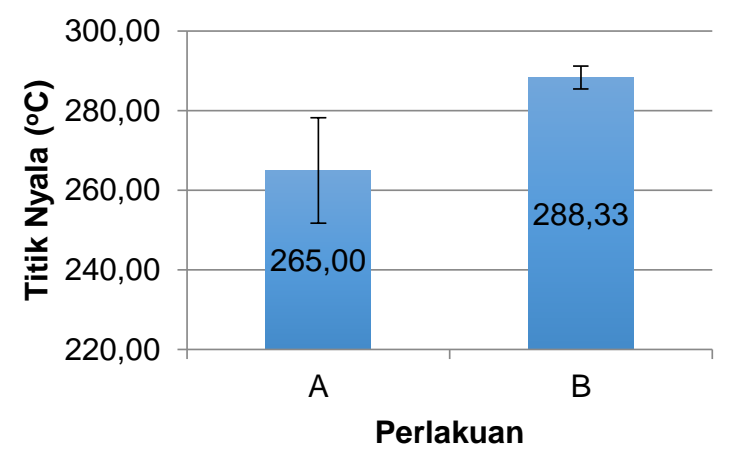

Gambar 9. Grafik Titik Nyala Biodiesel

Nilai titik nyala yang diperoleh sudah memenuhi batas syarat $\mathrm{SNI}$ yaitu di atas $100^{\circ} \mathrm{C}$. Menurut Ding (2014), titik nyala dari cairan yang mudah terbakar seperti biodiesel akan meningkat selaras dengan meningkatnya titik didih dari cairan tersebut. Menurut Yuan (2005), semakin panjang rantai karbon dari metil ester, maka semakin tinggi titik didihnya. Hal ini diduga menyebabkan nilai titik nyala perlakuan $B$ lebih tinggi dibandingkan dengan perlakuan $A$. Hal ini juga dibuktikan oleh temperatur destilasi perlakuan A yang mengacu kepada titik didih metil palmitat, yang memiliki titik didih lebih rendah serta rantai karbon yang lebih pendek. Hasil GC-MS juga menunjukkan bahwa sampel perlakuan A memiliki konsentrasi metil palmitat yang tinggi dibandingkan dengan sampel perlakuan B yang memiliki konsentrasi metil linoleat dan metil oleat yang tinggi.

Titik nyala biodiesel didefinisikan sebagai suhu terendah dimana dapat membentuk campuran yang mudah terbakar (Knothe et al., 2005). Biodiesel yang dihasilkan memiliki tingkat keamanan yang baik yaitu memiliki bahaya kebakaran dan ledakan yang sangat rendah. Titik nyala yang diperoleh mengindikasikan bahwa sampel biodiesel yang dihasilkan memiliki tingkat potensi kebakaran dan ledakan yang rendah. Dengan perlakuan B merupakan sampel yang lebih aman dibandingkan dengan perlakuan A.

\section{Angka Setana}

Angka setana merupakan salah satu karakteristik yang paling penting dalam penentuan kualitas biodiesel. Angka setana mengukur kesiapan dan kecepatan bahan bakar untuk terbakar secara otomatis ketika diinjeksikan pada mesin. Angka setana sangat dipengaruhi oleh komposisi dari bahan bakar dan dapat mempengaruhi tingkat kebisingan, 
emisi gas buang, dan kemampuan mesin untuk menyala (Van Gerpen, 1996; Holilah dkk., 2013).

Nilai angka setana yang diperoleh $71,50 \pm$ 1,45 pada perlakuan A dan 69,73 $\pm 2,02$ pada perlakuan B seperti yang ditunjukkan pada Gambar 10. Nilai angka setana yang ditetapkan dalam syarat mutu biodiesel SNI 7182:2015 yaitu bernilai minimum 51. Nilai angka setana dari sampel yang diperoleh sudah memenuhi SNI. Pada penelitian ini, angka setana diuji menggunakan persamaan Krisnangkura (1986) berdasarkan nilai bilangan iod serta bilangan penyabunan. Hal ini dilakukan karena keterbatasan jumlah sampel dan alat yang ada.

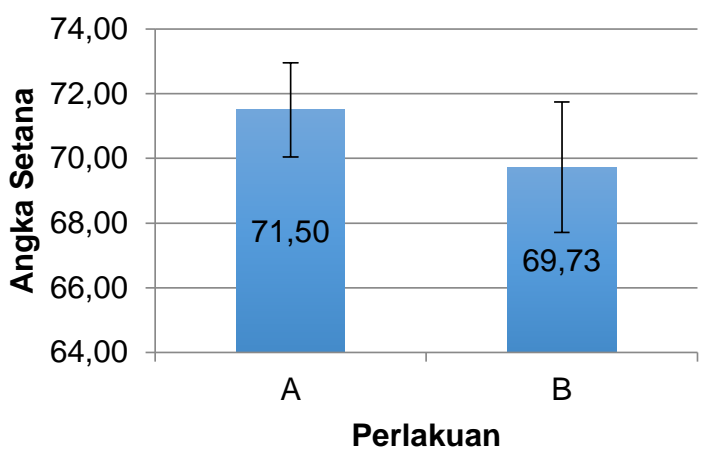

Gambar 10. Grafik Titik Nyala Biodiesel

Tabel 2. Rekapitulasi Data Hasil Penelitian

\begin{tabular}{|c|c|c|c|}
\hline \multirow{2}{*}{ Parameter } & \multicolumn{2}{|c|}{ Perlakuan } & \multirow{2}{*}{ Standar } \\
\hline & A & B & \\
\hline Rendemen (\%) & $16,08 \pm 0,59$ & $12,10 \pm 1,12$ & Tertinggi (Anggraini dkk., 2013) \\
\hline Viskositas Kinematik (mm²/s) & $2,69 \pm 0,16$ & $2,99 \pm 0,13$ & Terendah (Anggraini dkk., 2013) \\
\hline Densitas $\left(\mathrm{g} / \mathrm{cm}^{3}\right)$ & $872,27 \pm 3,47$ & $882,43 \pm 1,26$ & Terendah (Anggraini dkk., 2013) \\
\hline Kadar Air (\%) & $0,22 \pm 0,06$ & $0,24 \pm 0,17$ & Terendah(Barabas dan Todorut, 2011) \\
\hline Bilangan Asam (mg KOH/g minyak) & $0,27 \pm 0,03$ & $0,69 \pm 0,13$ & Terendah (Barabas dan Todorut, 2011) \\
\hline Bilangan lod (g I/2/100 g minyak) & $17,83 \pm 1,16$ & $19,96 \pm 2,79$ & Terendah (Barabas dan Todorut, 2011) \\
\hline Titik Nyala $\left({ }^{\circ} \mathrm{C}\right)$ & $265,00 \pm 13,23$ & $288,33 \pm 2,89$ & Tertinggi (Barabas dan Todorut, 2011) \\
\hline Angka Setana & $71,50 \pm 1,45$ & $69,73 \pm 2,02$ & Tertinggi (Anggraini dkk., 2013) \\
\hline
\end{tabular}

*) Nilai parameter yang diberi warna merupakan nilai terbaik dari kedua perlakuan

Angka setana sampel perlakuan A yang lebih tinggi dibandingkan dengan sampel perlakuan B. Hal ini diduga karena biodiesel yang dihasilkan pada sampel perlakuan A mengandung banyak komponen asam lemak jenuh. Menurut Van Gerpen (1996), semakin tinggi angka setana yang dihasilkan, maka semakin jenuh komponen yang terdapat di dalam bahan bakar. Hal ini dibuktikan oleh temperatur sampel perlakuan A mengacu kepada titik didih asam lemak jenuh metil palmitat. Selain itu, komponen asam lemak tak jenuh yang biasanya menyebabkan nilai angka setana yang rendah yaitu asam lemak linoleat dan linolenat memiliki titik didih yang dijadikan sebagai temperatur acuan perlakuan B. Tingkat kejenuhan bahan bakar juga ditunjukkan oleh hasil pengukuran bilangan iod yang dijadikan sebagai salah satu variabel persamaan perhitungan angka setana oleh Krisnangkura (1986).

Angka setana yang dihasilkan lebih tinggi dibandingkan dengan angka setana bahan bakar diesel pada umumnya yaitu 48 atau 51. Angka setana yang dihasilkan oleh biodiesel pada umumnya lebih tinggi dibandingkan dengan bahan bakar diesel biasa. Hal ini dikarenakan kandungan oksigen yang terdapat dalam biodiesel lebih tinggi dibandingkan bahan bakar diesel (Sivaramakrishnan, 2012) dan rantai karbon biodiesel lebih panjang sehingga baik untuk dijadikan bahan bakar (Van Gerpen et al., 2004).

Nilai angka setana yang dihasilkan melebihi dari nilai angka setana pada standar SNI yang ditentukan. Semakin tinggi nilai angka setana, maka semakin mudah pembakaran dan semakin singkat keterlambatan pembakaran bahan bakar (ignition delay). Hal ini menyebabkan berkurangnya pembentukan emisi NOx (Van Gerpen et al., 2007). Nilai angka setana sampel perlakuan A yang lebih tinggi dibandingkan dengan sampel perlakuan B mengindikasikan bahwa sampel perlakuan $A$ memiliki kemampuan pembakaran yang lebih baik dan memiliki keterlambatan pembakaran yang lebih singkat. 


\section{Rekapitulasi Hasil Penelitian}

Untuk menentukan hasil penelitian dengan perlakuan yang terbaik, data hasil penelitian yang telah dilakukan perlu direkapitulasi. Data hasil rekapitulasi disajikan pada Tabel 2 .

Pada Tabel 2, telah disajikan data rekapitulasi dari hasil penelitian yang dilakukan. Ditunjukkan pula nilai yang terbaik dari kedua perlakuan pada masing-masing parameter. Dari hasil tersebut, kemudian dilakukan penentuan hasil terbaik dengan menggunakan perhitungan. Perhitungan yang digunakan pada penelitian ini dilakukan dengan pembobotan metode rangking (Selamat, 2002). Setiap parameter diberikan bobot nilai berdasarkan peringkat yang direkomendasikan para ahli. Pada penelitian ini, peringkat parameter terbaik ditinjau dari dugaan kebutuhan mesin serta ditinjau dari kebutuhan proses produksi. Peringkat parameter disajikan pada Tabel 3 dan Tabel 4.

Tabel 3. Tabel Peringkat Kepentingan Parameter Ditinjau dari Kebutuhan Mesin

\begin{tabular}{cc}
\hline Peringkat & Parameter \\
\hline 1 & Rendemen \\
2 & Angka setana \\
3 & Densitas \\
4 & Titik nyala \\
5 & Belerang \\
\hline
\end{tabular}

(Muhaemin, 2016)

Pada Tabel 3 disajikan peringkat kepentingan parameter ditinjau dari kebutuhan mesin. Rendemen merupakan parameter penting dalam pengukuran efisiensi reaksi yang terjadi pada proses, serta dalam perolehan profit apabila ditinjau dari aspek ekonomi dan finansial. Angka setana merupakan parameter yang penting dalam mengukur keterlambatan dan kemudahan pembakaran bahan bakar.

Parameter densitas menentukan kualitas atomisasi serta besar energi yang dihasilkan oleh mesin. Sementara itu, titik nyala merupakan parameter yang menentukan keamanan dari bahan bakar. Titik nyala juga mengindikasikan residu alkohol di dalam biodiesel yang dapat mempengaruhi kualitas pembakaran.

Tabel 4. Tabel Peringkat Kepentingan Parameter Ditinjau dari Tingkat Efisiensi Proses

\begin{tabular}{cl}
\hline Peringkat & \multicolumn{1}{c}{ Parameter } \\
\hline 1 & Angka setana \\
2 & $\begin{array}{l}\text { Viskositas kinematik } \\
3\end{array}$ \\
& $\begin{array}{l}\text { Stabilitas oksidasi (Bilangan iod, Bilangan } \\
\text { asam, Kadar air) }\end{array}$ \\
4 & Densitas \\
\hline
\end{tabular}

(Nurjannah, 2016)
Parameter angka belerang penting dalam menandakan keberadaan belerang yang mengindikasikan kerusakan bahan bakar. Karena angka belerang merupakan bahan yang korosif dan menimbulkan polusi hasil pembakaran (Setiawati dan Edwar, 2012). Akan tetapi, parameter tersebut tidak diukur dikarenakan keterbatasan alat yang ada pada saat penelitian.

Pada Tabel 4 disajikan peringkat kepentingan parameter ditinjau dari proses. Angka setana, viskositas kinematik, serta densitas merupakan parameter yang dipengaruhi oleh komposisi asam lemak yang terdapat di dalam biodiesel. Ketiga parameter tersebut menunjukkan keberhasilan proses destilasi fraksinasi karena temperatur perlakuan yang mengacu kepada titik didih asam lemak yang terdapat di dalam biodiesel.

Pengujian stabilitas biodiesel terdiri dari tiga parameter, yaitu bilangan iod, bilangan asam, serta kadar air. Parameter tersebut penting dalam menentukan umur dan kualitas biodiesel terutama pada proses penyimpanan dan transportasi. Hal ini juga dikarenakan keterikatan parameter tersebut dengan kemampuan biodiesel terhidrolisis dan teroksidasi. Parameter bilangan asam dan kadar air juga merupakan parameter penting dalam proses produksi dikarenakan nilai yang tinggi dari kedua parameter tersebut akan mempersulit proses transesterifikasi.

Masing-masing parameter yang telah direkomendasikan akan diberikan bobot nilai sesuai dengan peringkatnya masing-masing. Bobot nilai yang diberikan kemudian dikalikan dengan perlakuan terbaik pada setiap parameter seperti yang disajikan pada Tabel 4. Sehingga dapat diketahui parameter terbaik ditinjau dari kebutuhan mesin dan kebutuhan proses produksi. Hasil perhitungan dari rekapitulasi akhir hasil pembobotan disajikan pada Tabel 5 . Dari data hasil rekapitulasi akhir yang disajikan pada Tabel 5, maka sampel terbaik apabila ditinjau dari kebutuhan mesin dan apabila ditinjau dari kebutuhan proses adalah sampel perlakuan $A$ dengan nilai bobot rekapitulasi sebesar 0,9 dan 1,5 secara berturut-turut. Apabila ditinjau dari kebutuhan mesin, sampel perlakuan A memiliki nilai terbaik pada parameter rendemen, angka setana, serta densitas. Sedangkan sampel perlakuan B memiliki nilai titik nyala terbaik. Hal ini menunjukkan bahwa sampel perlakuan A lebih baik digunakan untuk mesin, diduga memiliki 
kualitas pembakaran dan atomisasi yang lebih baik, serta memiliki kemampuan nyala mesin yang lebih baik. Rendemen sampel perlakuan A juga lebih besar, hal ini menandakan bahwa secara ekonomi biaya yang dikeluarkan akan menjadi lebih murah.

Tabel 5. Rekapitulasi Akhir Hasil Pembobotan

\begin{tabular}{lcc}
\hline Kategori Rekapitulasi & Perlakuan & $\begin{array}{c}\text { Bobot Nilai } \\
\text { Rekapitulasi }\end{array}$ \\
\hline Ditinjau dari kebutuhan & Perlakuan A & 0,9 \\
\cline { 2 - 3 } mesin & Perlakuan B & 0,1 \\
\hline Ditinjau dari kebutuhan \\
proses produksi & Perlakuan A & 1,5 \\
\cline { 2 - 3 } & Perlakuan B & 0,0 \\
\hline
\end{tabular}

Sampel perlakuan A juga memiliki nilai yang lebih baik pada parameter yang diperhitungkan apabila ditinjau dari kebutuhan proses, yakni angka setana, viskositas kinematik, bilangan asam, bilangan iod, kadar air, serta densitas. Sedangkan sampel perlakuan B tidak memiliki nilai terbaik pada parameter yang digunakan untuk penilaian kebutuhan proses. Hal ini menunjukkan bahwa sampel perlakuan A memiliki kestabilan yang lebih baik ditinjau dari nilai bilangan asam dan bilangan iod. Sampel perlakuan A juga memiliki kualitas pembakaran dan kualitas penyemprotan yang lebih baik dibandingkan dengan sampel perlakuan B.

\section{KESIMPULAN}

Berdasarkan penelitian yang telah dilakukan, kesimpulan yang dapat diambil ialah sebagai berikut:

1. Proses pembuatan biodiesel kemiri sunan dapat berhasil dilakukan dengan metode pemurnian destilasi fraksinasi pada temperatur $260-330^{\circ} \mathrm{C}$ dan $330-348^{\circ} \mathrm{C}$, tekanan $10,00 \mathrm{mmHg}$, panjang kolom 45 $\mathrm{cm}$, rasio refluks 2:1, equilibrium time 8 menit, dan temperatur kondensor $35^{\circ} \mathrm{C}$

2. Berdasarkan rekapitulasi penelitian, maka fraksi biodiesel kemiri sunan yang memiliki mutu terbaik apabila ditinjau dari kebutuhan mesin adalah fraksi biodiesel perlakuan $\mathrm{A}$ dengan temperatur destilasi $260-330^{\circ} \mathrm{C}$. Fraksi biodiesel kemiri sunan yang memiliki mutu terbaik apabila ditinjau dari kebutuhan proses juga merupakan fraksi biodiesel perlakuan $\mathrm{A}$ dengan temperatur destilasi $260-330^{\circ} \mathrm{C}$.

3. Hasil analisis mutu biodiesel kemiri sunan diperoleh bahwa kadar air, bilangan iod, angka setana, serta bilangan asam pada perlakuan B belum memenuhi nilai SNI 7182:2015. Sedangkan nilai viskositas kinematik, densitas, titik nyala, serta bilangan asam pada perlakuan A sudah memenuhi nilai SNI 7182:2015. Perolehan nilai terbaik dari rendemen, viskositas kinematik, densitas, kadar air, bilangan asam, bilangan iod, titik nyala, serta angka setana secara berturut-turut adalah $16,08 \% ; 2,69 \mathrm{~mm}^{2} / \mathrm{s} ; 872,27 \mathrm{~g} / \mathrm{cm}^{3} ; 0,22 \%$; $0,27 \mathrm{mg} \mathrm{KOH} / \mathrm{g}$ minyak; $17,83 \mathrm{~g} \mathrm{I}_{2} / 100 \mathrm{~g}$ minyak; $288,33^{\circ} \mathrm{C}$; dan 71,50 .

\section{DAFTAR PUSTAKA}

Altun, S., Yasar, F., Oner, C. 2010. The Fuel Properties of Methyl Ester Produced from Canola Oil-Animal Tallow Blends by BaseCatalyzed Transesterification. Interntional Journal of Engineering Research and Development 2(2):pp. 2-5.

Astra, I Made. 2010. Energi dan Dampak Terhadap Lingkungan. Jurnal Meteorologi dan Geofisika BMKG 11(2): hal. 131-139.

Atadashi, I.M., Aroua, M.K., Abdul Aziz, A.R., Sulaiman, N.M.N. 2012. The Effects of Water on Biodiesel Production and Refining Technologies: A Review. Renewable and Sustainable Energy Reviews 16(2012): pp. 3456-3470.

Barabas, I. and Todorut, I. 2011. Biodiesel Quality, Standards, and Properties. InDr. Gisela Montero (Ed.) Biodiesel Quality, Emissions, and By-Products (pp.3-28). Croatia: InTech.

Dewan Energi Nasional. 2014. Outlook Energi Indonesia 2014. Jakarta: Dewan Energi Nasional.

Ding, C., Zhou, D., Zhang, X. 2014. A Relationship between Flash Point and Boiling Point of the Flammable Liquids at Low Pressure. Applied Mechanics and Materials 664(2014): pp 210-21

Djenar, N.S. dan Lintang, N. 2012. Esterifikasi Minyak Kemiri Sunan (Aleurites trisperma) Dalam Pembuatan Biodiesel. BionaturaJurnal Ilmu-ilmu Hayatidan Fisik 14(3): hal. 215-221.

Joelianingsih, Armansyah, $H_{\text {., }}$ Tambunan, Nabetani, H., Sagara, Y., Abdullah, K. 2006. Perkembangan Proses Pembuatan Biodiesel Sebagai Bahan Bakar Nabati (BBN). Jurnal Keteknikan Pertanian 20: hal. 205-216.

Gilbert, J.C. and Martin, S.F. 2010. Experimental Organic Chemistry: A Miniscale and Microscale Approach, $5^{\text {th }}$ edition.USA: Cengage Learning. 
Hambali, E., Suryani, A., Dadang, Hariyadi, Hanafie, H., Reksowardojo, I.K., dkk. 2006. Jarak Pagar: Tanaman Penghasil Biodiesel. Depok: Penebar Swadaya.

Herman, M., Syakir, M., Pranowo, D., Saefudin, Sumanto. 2013. Kemiri Sunan (Reutealis trisperma (Blanco) Airy Shaw) Tanaman Penghasil Minyak Nabati dan Konservasi Lahan. Jakarta: IAARD Press.

Holilah. Utami, T.P., Prasetyoko, D. 2013. Sintesis dan Karakterisasi Biodiesel dari Minyak Kemiri Sunan (Reutealis trisperma) dengan Variasi Konsentrasi Katalis $\mathrm{NaOH}$. Jurnal MIPA 36(1): hal. 51-59.

Kementerian Energi dan Sumber Daya Mineral Republik Indonesia. 2013. Pengembangan Kemiri Sunan di Daerah Pertambangan. (Siaran Pers No. 57/PUSKOM KESDM/2013).

Knothe, G., Gerpen, J.V., Krahl, J. 2005. The Biodiesel Handbook. United States of America: AOCS Press.

Knothe, Gerhard. 2005. Dependence of Biodiesel Fuel Properties on the Structure of Fatty Acid Alkyl Esters. Fuel Processing Technology 86: pp. 1059-1070.

Knothe, Gerhard. 2008. "Designer" Biodiesel: Optimizing Fatty Ester Composition to Improve Fuel Properties. Energy \& Fuels 22: pp. 1358-1364.

Kusumaningsih, T., Pranoto, Saryoso, R. 2006. Pembuatan Bahan Bakar Biodiesel dari Minyak Jarak: Pengaruh Suhu dan Konsentrasi $\mathrm{KOH}$ pada Reaksi Transesterifikasi Berbasis Katalis Basa. Jurnal Bioteknologi 3(1): hal. 20-26.

Krisnangkura, Kanit. 1986. A SImple Method for Estimation of Cetane Index of Vegetable Oil Methyl Esthers. Journal of the American Oil Chemists' Society, 63(2): pp. 562-563.

Lister, T. and Renshaw, J. 2000. Understanding Chemistry for Advanced Level, $3^{\text {rd }}$ edition.Cheltenham: Nelson Thomes.
Nurjanah, S., Lestari, D.S., Widyasanti, A., Zain, S. 2015. The Effect of $\mathrm{NaOH}$ Concentration and Length of Trans-esterification Time on Characteristic of FAME from Reutealis trisperma (Kemiri Sunan). International Journal on Advanced Science Engineering Information Technology Vol 5(2015) No. 1: pp. 52-56

Pranowo, D., Syakir, M., Prastowo, B., Herman, M., Aunillah, A., Sumanto. 2014. Pembuatan Biodiesel dari Kemiri Sunan (Reutealis trisperma (Blanco) Airy Shaw) dan Pemanfaatan Hasil Samping. Jakarta: IAARD Press.

Ramsden, E.N. 2012. Key Science Chemistry, $3^{\text {rd }}$ edition. United Kingdom: Nelson Thomes.

Romano, S.D., and Sorichetti, P.A. 2011. Dielectric Spectroscopy in Biodiesel Production and Characterization. London: Springer-Verlag.

Selamat, Muhammad Banda. 2002. Modul Praktikum Sistem Informasi Geografis Jurusan Ilmu Kelautan FIKP-UH. Makassar: Universitas Hasanudin.

Van Gerpen, Jon. 1996. Cetane Number Testing of Biodiesel. lowa: lowa State University.

Van Gerpen, J.H., Peterson, C.I., Goering, C.E. 2007. Biodiesel: An Alternative Fuel for Compression Ignition Engines. United Stated of America: American Society of Agricultural and Biological Engineers.

Van Gerpen, J., Shanks, B., Pruszko, R. Clements, D., Knothe, G. 2004. Biodiesel Production Technology. Colorado: National Renewable Energy Laboratory.

Yang, S.T., El-Ensashy, H., Thongchul, N. 2013. Bioprocessing Technologies in Biorefinery for Sustainable Production of Fuels, Chemicals, and Polymers. New Jersey: John Wiley \& Sons.

Yuan, W., Hansen, A.C., Zhang, Q. 2005. Vapor Pressure and Normal Boiling Point Prediction for Pure Methyl Esters and Biodiesel Fuels. Fuel 84(2005): pp. 943950. 